\title{
Urgensi Pengaturan Reklamasi Pantai Di Wilayah Pesisir Selatan Madura
}

\author{
Rina Yulianti, Mufarrijul Ikhwan, Nurus Zaman \\ Fakultas Hukum Universitas Trunojoyo Madura \\ Email : abundayuliantirina@gmail.com
}

\begin{abstract}
This research aims to get the characteristic of the reclamation land tenure, inventorying policies related to the reclamation and legal regulation models of reclamation in Madura. This empirical legal research results that the most of land tenure reclaimed comes from the head of village permission. Policies of the reclamation in fact sectoral even though fourth districts having local regulation on spatial planning. Local regulation about reclamation is needed for coordination and synchronization between central and local authorities, for supporting Act No. 27 Year 2007 about Coastal Management Areas and Small Islands, also Presidential Regulation No. 122 year 2012 about Reclamation.
\end{abstract}

Key words : Regulation, Reclamation, Coastal

\begin{abstract}
Abstrak
Penelitian ini bertujuan untuk mendapatkan karakteristik penguasaan hak atas tanah hasil reklamasi, inventarisir kebijakan terkait reklamasi dan rumusan model pengaturan hukum reklamasi di Madura. Hasil penelitian hukum empiris ini mendapati bahwa kebanyakan penguasaan tanah hasil reklamasi berasal dari ijin yang diberikan oleh Kepala Desa. Kebijakan terkait pelaksanaan reklamasi masih bersifat sektoral meskipun keempat kabupaten telah mempunyai Peraturan Daerah tentang RTRW. Diperlukan "Peraturan Daerah" tentang reklamasi untuk menciptakan koordinasi dan sinkronisasi antara kewenangan pusat dan daerah. Peraturan Daerah tentang reklamasi ini untuk mendukung pelaksanaan UU nomor 27 tahun 2007 tentang Pengelolaan Wilayah Pesisir dan Pulau-Pulau Kecil, juga Peraturan Presiden tentang reklamasi.
\end{abstract}

Kata Kunci : Pengaturan, Reklamasi, Pantai

\section{A. Pendahuluan}

Beroperasinya jembatan Suramadu telah membawa berbagai dampak perubahan pada masyarakat Madura, tidak hanya yang bermukim di sekitar kaki jembatan Suramadu, mereka yang berada di sepanjang jalur propinsi pesisir selatan 
Madura mulai Bangkalan sampai Sumenep berlomba-lomba mencari berkah Suramadu.

Di sepanjang pesisir pantai selatan itu banyak sekali aktivitas pembangunan, baik yang dilakukan oleh masyarakat maupun pemerintah. Adanya reklamasi pantai, penambangan batu dan pasir, bangunan rumah, gudang, pabrik dan gedung milik pemerintah, mengakibatkan jarang sekali ditemukan hutan mangrove, bahkan tanaman bakau sebagai salah satu penyusun hutan mangrove tiap tahun jumlahnya semakin menyusut. Kegiatan ini menyebabkan abrasi pantai di sepanjang jalan raya yang menghubungkan Sampang dan Pamekasan, Madura, Provinsi Jawa Timur yaitu di jalan raya desa Sejati, Kec. Camplong, Sampang, hal ini telah mengakibatkan tangkis laut rusak. Hal yang sama juga terjadi di sepanjang pesisir pantai pulau Sapeken, Sumenep. Dampak dari rusaknya tangkis laut itu menyebabkan jalan raya tergerus, banyak tanaman mangrove yang mati, daerah pesisir laut menjadi gersang, serta merusak aneka jenis tanaman lainnya. (sumber : Syaiful Rohman, “Abrasi Pantai dan Hutan Mangrove”, http : // green.kompasiana.com/ penghijauan /2011/08/06/abrasi - pantai - dan -hutan-mangrove-384428.html, di akses 24 Maret 2012)

Budaya masyarakat mereklamasi pantai juga terjadi di wilayah kepulauan timur Madura, tepatnya di Pulau Saobi yang masuk wilayah Kabupaten Sumenep. Seluruh lahan di sepanjang pesisir pantai Pulau Saobi adalah hasil menimbun masyarakat kepulauan tersebut dan semuanya tidak bersertifikat. (sumber : Radar Madura “Lahan Sepanjang Pantai di Pulau Saobi Tidak Bersertifikat, 17 Maret 2012)

Budaya mereklamasi atau menimbun pantai ini kalau di biarkan dan tidak diatur secara serius akan membawa dampak negatif yang besar. Permasalahan yang berdasarkan latar belakang yang ada, (1) tidak adanya norma dan penegakan hukum yang secara tegas dan khusus mengatur kegiatan reklamasi pantai di sepanjang pesisir pantai selatan Madura, (2) Lemahnya koordinasi antara Pemerintah Daerah setempat dan BPN sebagai otoritas penguasaan hak atas tanah dalam menangani masalah Reklamasi pantai. 


\section{B. Metode Penelitian}

penelitian ini adalah penelitian hukum empiris atau penelitian hukum non doktrinal disebut juga sebagai penelitian hukum sosiologis (sosio legal research) yang dalam penelitian ini menitikberatkan terhadap bekerjanya hukum dimasyarakat (Bambang Sunggono, 1998 : hal. 43), dengan pendekatan perundang-undangan (statute approarch), pendekatan kasus (case approarch) dan pendekatan konseptual (conceptual approach). Data dalam penelitian ini merupakan data primer yang didapat dari sumber di lokasi Bangkalan, Sampang, Pamekasan, dan Sumenep. Sebagai sumber informasi atau informan kunci dari penelitian ini adalah pihak-pihak yang terlibat langsung dalam proses perumusan model pengaturan hukum reklamasi pantai di wilayah pesisir selatan Madura. Untuk keperluan itu yang dapat dijadikan sebagai sumber informasi yaitu:

a. Masyarakat Umum yang melakukan kegiatan Reklamasi di kawasan pantai sepanjang pesisir selatan Madura

b. Tokoh Formal, pihak-pihak yang masuk dalam struktur organisasi pemerintahan, mulai dari tingkat Desa sampai dengan tingkat Kabupaten, yang terlibat dalam kegiatan Reklamasi.

c. Badan Hukum ataupun Badan Usaha yang terlibat dalam kegiatan Reklamasi di kawasan pantai sepanjang pesisir selatan Madura.

d. Pihak Badan Pertanahan Nasional yang dalam hal ini diwakili kantor pertanahan di masing-masing Kabupaten

e. Legislator di daerah masing-masing kawasan.

f. Pihak lain yang informasinya memberikan kontribusi/pertimbangan dalam upaya melakukan rekonstruksi yuridis Reklamasi Pantai di Wilayah Pesisir Selatan Madura.

Sumber data sekunder diperoleh dari kantor-kantor pemerintahan mulai dari tingkat desa sampai Kabupaten, kantor-kantor penegak hukum, dan kantor LSM.

\section{Teknik Pengumpulan Data}


Untuk memperoleh data dalam penelitian ini dengan menggunakan data primer dan data sekunder. Cara memperoleh data primer adalah dengan Teknik wawancara mendalam (dept interview). Sedangkan data sekunder diperoleh melalui studi dokumen.

Lewat teknik wawancara, akan digali data selengkap-lengkapnya. Teknik wawancara yang dipakai disini adalah wawancara semi-terstruktur, yaitu berupa daftar pertanyaan mengenai pokok masalah sehingga memungkinkan adanya variasi pertanyaan yang disesuaikan dengan situasi ketika wawancara dilakukan. Sedangkan data sekunder diperoleh dari kantor-kantor pemerintahan mulai dari tingkat desa sampai Kabupaten, kantor badan pertanahan.

\section{Tehnik Pengolahan Data}

Data kualitatif yang dikumpulkan dalam proses pengumpulan data akan di sajikan dalam paparan (deskripsi) mendalam dan terfokus. Dalam hal ini akan dilakukan verifikasi data kualitatif yang berhubungan dengan topik penelitian.

\section{Hasil Penelitian dan Pembahasan}

\section{Penguasaan Tanah hasil Reklamasi di Pesisir Pantai Selatan Madura}

Dalam UU 27/2007 sebagaimana dirubah dalam UU 1/2014 mengatur mengenai reklamasi hanya ada di satu pasal saja yaitu Pasal 34, sedangkan pada Pasal 1 butir (23) memberikan definisi bahwa "reklamasi adalah kegiatan yang dilakukan oleh setiap orang dalam rangka meningkatkan manfaat sumber daya lahan ditinjau dari sudut lingkungan dan sosial ekonomi dengan cara pengurugan, pengeringan lahan atau drainase”.

Pasal 34 UU 27/2007 menentukan bahwa :

(1) Reklamasi Wilayah Pesisir dan Pulau-Pulau Kecil dilakukan dalam rangka meningkatkan manfaat dan/atau nilai tambah Wilayah Pesisir dan Pulau-Pulau Kecil ditinjau dari aspek teknis, lingkungan, dan sosial ekonomi.

(2) Pelaksanaan Reklamasi sebagaimana dimaksud pada ayat (1) wajib menjaga dan memperhatikan:

a. keberlanjutan kehidupan dan penghidupan Masyarakat;

b. keseimbangan antara kepentingan pemanfaatan dan kepentingan pelestarian fungsi lingkungan Pesisir dan Pulau-Pulau Kecil; serta 
c. persyaratan teknis pengambilan, pengerukan, dan penimbunan material.

(3) Perencanaan dan pelaksanaan Reklamasi diatur lebih lanjut dengan Peraturan Presiden.

Preferensi terhadap penguasaan tanah hasil reklamasi di empat Kabupaten di wilayah Madura berdasarkan pihak yang menguasai, alas hak yang dikuasai hampir semuanya mempunyai karakteristik yang sama. Akan tetapi untuk lebih jelasnyan akan di bahas berdasarkan wilayah pemerintahan masing-masing Kabupaten.

Di Kabupaten Bangkalan daerah pesisir selatan berada di Kecamatan Kamal, Socah, Labang, Kwanyar dan Modung. Terdapat dua preferensi penguasaan tanah hasil reklamasi, yang membedakan bila dikuasai oleh perorangan maka alas haknya berasal dari : hasil mengurug pantai oleh warga, sedangkan penguasaan oleh Badan Hukum/Badan Usaha dari ijin reklamasi yang dikeluarkan baik oleh Kepala Desa, ada juga perusahaan yang menguasahi dengan alas hak jual beli dari warga masyarakat sekitar pantai yang telah mendapatkan tanah dari hasil mengurug pantai. (sumber : Wawancara tertutup dengan aparatur pemerintahan desa, tokoh masyarakat di pesisir selatan Bangkalan dan Kantor Pertanahan Bangkalan kurun waktu April sampai dengan Agustus 2013)

Kegiatan reklamasi di empat wilayah kecamatan di Kabupaten Bangkalan lebih banyak pada kegiatan yang bersifat “mengurug” hal ini berdasarkan pada Pasal 1 angka (23) UU 1/2014 jo Pasal 1 ayat (1) ketentuan umum Peraturan Presiden nomor 122 tahun 2012 tentang Reklamasi di wilayah pesisir dan pulau-pulau kecil.

Pernah menjadi perhatian adalah demonstrasi ke BPN/Kantor Pertanahan Kabupaten Bangkalan, yang dilakukan oleh sejumlah massa yang mengatasnamakan front mahasiswa penyelamat lahan pantai (FM-Palapa) pada awal Juli 2013 terkait terbitnya sertifikat di atas tanah hasil reklamasi di Kecamatan Socah. Pendemo menyayangkan penerbitan sertifikat tersebut karena menurut mereka adanya tanah tersebut telah merusak lingkungan dan mata pencaharian nelayan tradisional di Kecamatan Socah dan Kecamatan Bangkalan Kota. (sumber : 
http://www.maduracorner.com/lahan-reklamasi-dijadikan-hak-milik-fm-palapa-lurukbpn/, di akses pada 12 Juli 2013)

Pihak BPN dalam hal ini Kantor Pertanahan Kabupaten Bangkalan tidak merasa melakukan hal yang menyalahi aturan terkait terbitnya sertifikat atas tanah hasil reklamasi. Kepala Kantor Pertanahan menyatakan sebelum sertifikat di terbitkan seluruh persyaratan antara lain ijin prinsip, ijin reklamasi, ijin bangunan (IMB), dan UKL-UPL yang dikeluarkan oleh Pemerintah Kabupaten Bangkalan telah terpenuhi, dengan demikian tidak ada alasan bagi BPN untuk tidak menerbitkan sertifikat. Oleh karenanya BPN mengangggap keliru tuduhan non prosedural pada saat mengeluarkan sertifikat dengan hak kelola dan hak guna bangunan terhadap tanah hasil reklamasi tersebut. (sumber : wawancara tertutup dengan Bapak Wahyudi Ka.TU Kantor Pertanahan Bangkalan, tanggal 15 Juli 2013)

FM Palapa yang menuduhkan adanya permainan mafia tanah di sepanjang pesisir pantai di kecamatan Socah dan Bangkalan Kota semata-mata mengejar keuntungan belaka dengan menjual kepada investor tanpa mempertimbangkan kerusakan lingkungan dan mata pencaharian nelayan tradisional di sekitarnya.

Tanah hasil reklamasi yang berada di sekitar pesisir selatan kecamatan Kamal, Labang, Kwanyar dan Modung, kebanyakan tanah hasil reklamasi dilakukan untuk memperluas lahan mereka yang sudah ada sebelumnya, bahkan menimbun atau mengurug baru untuk tujuan tertentu. Hasil penelusuran kami bahwa tanah reklamasi tersebut di fungsikan untuk rumah tinggal, usaha dan yayasan pendidikan. Masyarakat menyatakan mereka menguasai secara turun temurun baik dengan hibah maupun waris, ada juga beberapa yang dilakukan dengan jual beli dan menurut mereka terkait penguasaan tersebut adalah syah karena telah membayar pajak bumi dan bangunan melalui Kepala Desa. (sumber : wawancara tertutup dengan warga masyarakat di sepanjang pesisir selatan Bangkalan Mei-Agustus 2013)

Berbeda lagi dengan desa Kwanyar Barat yang menolak adanya kegiatan reklamasi kecuali untuk kepentingan umum.Warga melarang adanya kegiatan mengurug pantai karena bisa merusak lingkungan dan menyebabkan nelayan tidak mendapatkan lahan untuk memarkir perahu mereka. Warga desa Kwanyar Barat sadar 
betul dengan mayoritas berprofesi sebagai nelayan maka mereka harus menjaga kelestarian lingkungan laut dengan baik. Kontradiksi dengan desa sebelahnya, yaitu Desa Pesanggrahan, terdapat bangunan tiga lantai Sekolah Menengah Kejuruan dan Pom Bensin yang berdiri di atas tanah hasil mengurug pantai. Di sepanjang pesisir pantai wilayah Kecamatan Kwanyar ke arah timur menuju wilayah kecamatan Modung dan masuk wilayah Kecamatan Sreseh Kabupaten Sampang semakin banyak di jumpai kegiatan mereklamasi pantai oleh warga. (sumber : wawancara tertutup dengan warga masyarakat di sepanjang pesisir selatan Bangkalan Mei-Agustus 2013)

Lain halnya dengan wilayah pesisir pantai di Kecamatan Modung, masyarakat menyampaikan bahwa untuk bisa mendapatkan tanah hasil reklamasi sangatlah mudah, cukup mendatangi Kepala Desa urusan ijin dan sebagaianya menjadi beres. Banyak kami temui lahan-lahan hasil reklamasi baru di sepanjang pantai yang mendekati kantor kecamatan Modung. (sumber : wawancara tertutup dengan warga masyarakat di sepanjang pesisir selatan Bangkalan Mei-Agustus 2013)

Wilayah Kabupaten Sampang adalah daerah pesisir selatan Madura yang mempunyai aktifitas paling tinggi dalam melakukan kegiatan reklamasi di bandingkan dengan tiga Kabupaten yang lain.

Permasalahan reklamasi tanah di sepanjang pesisir selatan di wilayah Kecamatan Camplong dan Kecamatan Sreseh yang banyak menyedot perhatian. Terutama di Kecamatan Camplong, dengan lokasinya yang strategis menyebabkan banyaknya lahan-lahan baru yang di peroleh dengan cara mengurug pantai.

Saat ini baik dari pemerintah Kabupaten Sampang maupun pihak Badan Pertanahan Nasional (BPN) / Badan Pertanahan Kabupaten Sampang sama-sama tidak mau di anggap sebagai lembaga yang paling bertanggungjawab atas maraknya kegiatan reklamasi. Masing-masing merasa tidak melakukan hal yang melanggar hukum, BPN melaksanakan kewajibannya berdasarkan prosedur yang ada sedangkan pemerintah untuk saat ini tidak pernah mengeluarkan rekomendasi/ijin mereklamasi.

Hasil penelusuran kami sebagain besar lahan yang sudah di urug di pesisir pantai tersebut hanya mendapatkan ijin dari Kepala Desa. Masyarakat mengajukan ijin melakukan reklamasi kemudian diminta untuk membuat pernyataan sewaktu 
waktu harus bersedia bila tanahnya di minta oleh negara bila di butuhkan. Kami menemukan dua kemungkinan lahirnya hak penguasaan atas tanah hasil reklamasi tersebut :

- Lahan/Tanah urug tanpa Bangunan, maka alur perijinan bisa dari Kepala Desa saja atau lanjut sampai dengan rekomendasi Bupati, yang mendapatkan rekomendasi dan ijin dari Bupati maka Kantor Pertanahan akan mengeluarkan sertifikat dan konsekuensinya akan dikeluarkan juga IMB oleh Dinas Perijinan Terpadu, bila tidak ada rekomendasi dari Bupati dan persyaratan lainnya hanya sampai di Kepala Desa saja dan oleh Kepala Desa akan di uruskan pajak tanahnya ke Dispendaloka.

- Lahan/Tanah urug dengan Bangunan, BPN dalam hal ini kantor pertanahan kabupaten akan mengeluarkan sertifikat dengan dilengkapinya semua persyaratan meskipun hanya ijin melakukan reklamasi dari Kepala Desa, dengan adanya sertifikat ini Dinas Perijinan Terpadu akan mengeluarkan IMB. (sumber : hasil penelusuran lapangan berdasarkan wawancara dengan aparatur pemerintahan desa dan pemkab Sampang serta masyarakat pada Mei-Agustus 2013)

Dengan demikian di Kabupaten Sampang terkait preferensi masyarakat terhadap pengauasaan tanah hasil reklamasi mempunyai latar belakang perolehan yang berbeda-beda. Kepala Desa Labuhan Kecamatan Sreseh menyampaikan bahwa tanah-tanah hasil reklamasi di sepanjang pesisir pantai tersebut semuanya mempunyai bukti pembayaran pajak. Tetapi hampir tidak ada yang bersertifikat. Warga yang ditemui menyatakan mereka bahkan tidak tahu menahu terhadap status tanah yang mereka kuasai, banyak yang menjawab mendapatkan dari waris, maupun beli, dan semuanya melalui Kepala Desa. (sumber : wawancara tertutup dengan Kades Labuhan pada 8 Juli 2013)

Di Kabupaten Pamekasan berdasarkan penelusuran ke daerah pesisir selatan terhadap tanah hasil reklamasi yang di dapatkan adalah sebagai berikut :

- Menyewa ke Desa

- $\quad$ Ijin Mereklamasi ke Kepala Desa 
Mekanisme penguasaan tanah hasil reklamasi di Kabupaten pamekasan hampir sama dengan daerah-daerah lainnya. Andil besar ada di Kepala Desa, kebanyakan tanah di pergunakan baik sebagai rumah tinggal, usaha non tambak maupun tambak.

Menelusuri tanah hasil reklamasi kami temukan di tiga Kecamatan di wilayah pesisir selatan, yaitu Kecamatan Pragaan, Saronggi dan Gapura.

\section{Desa Aeng Panas Kecamatan Pragaan}

Kebanyakan masyarakat desa Aeng Panas mendirikan bangunan-bangunan di daerah sekitar pesisir pantai untuk tempat tinggal dan usaha. Menurut masyarakat daerah pesisir pantai desa Aeng Panas berpendapat bahwa mendirikan bangunan untuk tempat usaha warung tempat makan dan warnet (warung internet) di daerah tersebut karena dekat dengan jalan antar provinsi.

Jumlah tanah yang dipergunakan untuk reklamasi di desa Aeng Panas tersebut kurang lebih ada 3 bidang yang dipergunakan untuk tempat tinggal dan 4 bidang yang digunakan sebagai tempat usaha.

Kegiatan mereklamasi pantai yang dilakukan oleh masyarakat desa Aeng Panas Kecamatan Pragaan ternyata tidak ada kordinasi dengan Pemerintah Kabupaten Sumenep. (sumber : wawancara dengan masyarakat desa dan sekretaris desa Aeng panas, pada 26 Juni 2013)

\section{Desa Tanjung Kecamatan Saronggi}

Mekanisme masyarakat mendapatkan tanah hasil reklamasi di desa Tanjung dengan cara inisiatif sendiri atau tanpa meminta ijin dari siapapun, sehingga kepala desa tidak tahu menahu dan tiba-tiba sudah terdapat bangunan di daerah pesisir desa Tanjung tersebut. (wawancara tertutup dengan Kepala DesaTanjung, pada 15 Juli 2013)

Kebanyakan masyarakat desa Tanjung mendirikan bangunan-bangunan di daerah sekitar pesisir pantai dipergunakan untuk tempat tinggal dan usaha. Mereka berpendapat bahwa mendirikan bangunan untuk tempat usaha di daerah tersebut karena dekat dengan jalan raya. 
Jumlah tanah hasil reklamasi di desa Tanjung tersebut kurang lebih ada 10 bidang untuk tempat tinggal dan 2 bidang yang digunakan sebagai tempat usaha.

\section{Desa Gersik Putih dan Andulang Kecamatan Gapura}

Di Kecamatan Gapura kegiatan mereklamasi berbeda dengan daerah lain karena peruntukannya banyak sebagai lahan usaha tambak ikan dan tambak garam. Setiap tahunnya kegiatan mereklamasi untuk usaha tambak ini semakin meningkat terutama di desa Gersik Putih dan Andulang.

Kondisi ini mulai meresahkan dan membuat khawatir masyarakat kedua desa tersebut karena sebagaian besar bermata pencaharian sebagai nelayan tradisional. Mereka takut reklamasi besar-besaran yang dilakukan oleh perusahaan swasta tersebut akan menghilangkan penghasilan mereka akibat rusaknya lingkungan. Disamping itu pesisir yang beralih fungsi sebagai lahan tambak tersebut akan menganggu bahkan menyulitkan kegiatan pelayaran mereka.

Akhirnya warga kedua desa tersebut melakukan unjuk rasa dengan cara menancapkan papan untuk larangan kegiatan reklamasi. Kasus ini terjadi pada awal tahun 2012. (Surabaya Post, diakses 8 Juli 2013)

\section{Kebijakan Penguasa Setempat tentang penguasaan dan Pemilikan Tanah Hasil Reklamasi}

Hampir di seluruh kabupaten di wilayah Madura menerapkan kebijakan reklamasi ini masih bersifat sektoral. Bahkan bisa dikatakan minim koordinasi antar sektor dan lintas lembaga.

Kecenderungan tidak mau disalahkan akibat menjamurnya kegiatan reklamasi di pesisir selatan Madura menyebabkan masing-masing instansi pemerintah berargumen berdasarkan tugas dan wewenangnya masing-masing.

Pihak-pihak yang terkait dengan pelaksanan kegiatan reklamasi dan lahan hasilnya antara lain :

Table 1. Pihak-Pihak Terkait Kegiatan Reklamasi

\begin{tabular}{|c|l|l|}
\hline No & \multicolumn{1}{|c|}{ Pihak Terkait } & \multicolumn{1}{|c|}{ Kewenangan } \\
\hline 1 & Kepala Desa/Lurah & Menyetujui ijin reklamasi \\
\hline 2 & Bupati Kepala Daerah & Ijin melaksanakan reklamasi/lokasi \\
\hline 3 & Bappeda & RTRW \\
\hline
\end{tabular}




\begin{tabular}{|c|l|l|}
\hline 4 & Kantor Perijinan & IMB \\
\hline 5 & BPN/Kantor Pertanahan Kota/Kab. Setempat & Menerbitkan Sertifikat \\
\hline 6 & Dispendaloka & Pembayaran Pajak \\
\hline 7 & $\begin{array}{l}\text { Dinas Kelautan, Perikanan dan Peternakan } \\
\text { /DKP }\end{array}$ & $\begin{array}{l}\text { Pengawasan dan Pengendalian } \\
\text { lingkungan laut dan ekosistem laut }\end{array}$ \\
\hline
\end{tabular}

Sumber : Hasil penelusuran tim peneliti berdasarkan kewenangan Instansi terkait

Table di atas menggambarkan betapa banyaknya pihak-pihak yang terlibat dalam kegiatan reklamasi. Lembaga teknis pemerintah masih bekerja secara sendirisendiri, sehingga kebijakan yang ada terkait pelaksanaan reklamasi menjadi tidak berkesinambungan. Masing-masing lembaga sudah merasa bekerja sesuai kewenangannya, dan yang menjadi permasalahan adalah tidak adanya koordinasi dalam membuat kebijakan terkait pelaksanaan Reklamasi.

Meskipun hal yang paling mudah untuk menata pelaksanaan reklamasi adalah berdasarkan Rencana Tata Ruang Wilayah (RTRW) dan ini menjadi kewenangan Bapedda tetapi mereka merasa tidak pernah di ajak berkoordinasi dengan Kantor Pertanahan dalam menerbitkan Sertifikat tanah hasil reklamasi.

Ironinya dari keempat kabupaten di wilayah Madura sudah memiliki Peraturan Daerah tentang RTRW yaitu :

1. Peraturan Daerah Kabupaten Bangkalan Nomor 10 Tahun 2009 tentang Rencana Tata Ruang Wilayah Kabupaten Bangkalan (Lembaran Daerah Kabupaten Bangkalan Tahun 2009 Nomor 4/E)

2. Peraturan Daerah Kabupaten Sampang Nomor 7 Tahun 2012 tentang Rencana Tata Ruang Wilayah kabupaten Sampang Tahun 2012-2032

3. Peraturan daerah Nomor 16 Tahun 2012 Kabupaten Pamekasan tentang Rencana Tata Ruang Wilayah Kabupaten Pamekasan Tahun 2012-2032

4. Peraturan daerah Nomor 12 Tahun 2013 Kabupaten Sumenep tentang Rencana Tata Ruang Wilayah Kabupaten Sumenep Tahun 2013-2033

Peraturan daerah tentang Tata Ruang sebenarnya bisa menjadi tolok ukur dalam mengambil kebijakan terkait reklamasi, akan tetapi tidak adanya koordinasi 
antar lembaga teknis tersebut menjadi hambatan tersendiri. Untuk memudahkan pengaturannya memang sudah seharusnya keempat kabupaten tersebut mempunyai Peraturan daerah tentang Reklamasi.

\section{Rumusan Model Pengaturan Hukum Budaya Reklamasi Pantai di Wilayah Pesisir Selatan Madura}

Berbicara pengaturan hukum mengenai reklamasi di daerah, alangkah baiknya kita ketahui secara komprehensif peraturan-peraturan terkait :

1. Undang-Undang Nomor 27 Tahun 2007 tentang Pengelolaan Wilayah Pesisir dan Pulau-Pulau Kecil (Lembaran Negara Republik Indonesia Tahun 2007 Nomor 84, Tambahan Lembaran Negara Republik Indonesia Nomor 4739);

2. Peraturan Pemerintah Republik Indonesia Nomor 16 tahun 2004 tentang Penatagunaan tanah

3. Peraturan Presiden Republik Indonesia Nomor 122 tahun 2012 Tentang Reklamasi di Wilayah Pesisir dan Pulau-Pulau Kecil;

4. Peraturan Menteri Kelautan dan Perikana Nomor 17 Tahun 2013 Tentang Izin Reklamasi

5. Peraturan Menteri Pekerjaan Umum Nomor 40/PRT/M/2007 tentang Pedoman Perencanaan Tata Ruang Kawasan Reklamasi Pantai

Pasal 33 ayat (3) Undang-undang Dasar 1945 mengatur bahwa “ Bumi, air dan kekayaan alam yang terkandung di dalamnya dikuasi oleh Negara dan dipergunakan untuk sebesar-besar kemakmuran rakyat “. Ketentuan ini menjadi dasar filosofis bagi diundangkannya Undang-Undang Nomor 27 Tahun 2007 tentang Pengelolaan Wilayah Pesisir Dan Pulau-Pulau Kecil Lembaran Negara Republik Indonesia Nomor 84, Tambahan Lembaran Negara Republik Indonesia Niomor 4739 disahkan di Jakarta tanggal 17 Juli 2007 (Selanjutnya di sebut sebagai UU 27/2007), yang menimbang :

a. bahwa Wilayah Pesisir dan Pulau-Pulau Kecil merupakan bagian dari sumber daya alam yang dianugerahkan oleh Tuhan Yang Maha Esa dan merupakan kekayaan yang dikuasai oleh negara, yang perlu dijaga kelestariannya dan 
dimanfaatkan untuk sebesar-besar kemakmuran rakyat, baik bagi generasi sekarang maupun bagi generasi yang akan datang;

b. bahwa Wilayah Pesisir dan Pulau-Pulau Kecil memiliki keragaman potensi sumber daya alam yang tinggi, dan sangat penting bagi pengembangan sosial, ekonomi, budaya, lingkungan, dan penyangga kedaulatan bangsa, oleh karena itu perlu dikelola secara berkelanjutan dan berwawasaan global, dengan memperhatikan aspirasi dan partisipasi masyarakat, dan tata nilai bangsa yang berdasarkan norma hukum nasional;

c. bahwa berdasarkan pertimbangan sebagaimana dimaksud dalam huruf a, dan huruf b, perlu membentuk Undang-Undang tentang Pengelolaan Wilayah Pesisir dan Pulau-Pulau Kecil;

Sekalipun Indonesia belum memiliki suatu undang-undang tersendiri yang secara khusus mengatur tentang reklamasi, tetapi telah ada sejumlah peraturan yang berkenaan dengan reklamasi pantai dan laut, walaupun secara partial. PeraturanPeraturan tersebut mencakup (Flora Pricilla Kalalo, 2009 : hal. 103) :

1. Pasal 34 UU 27/2007. Melalui pasal ini diberikan : 1) Kepastian hukum terhadap pelaksana reklamasi pantai, yaitu reklamasi pantai merupakan pranata hukum yang sah, walaupun harus dengan memperhatikan sejumlah syarat ; dan 2) kepastian hukum terhadap masyarakat, yang terdiri dari Masyarakat Adat dan Masyarakat Lokal yang bermukim di Wilayah Pesisir dan Pulau-Pulau Kecil (Pasal 1 butir 32), berupa jaminan keberlanjutan kehidupan dan penghidupan masyarakat perkotaan.

2. Pasal 12 Peraturan Pemerintah Nomor 16 Tahun 2004 tentang Penatagunaan Tanah yang menentukan bahwa tanah yang berasal dari tanah timbul atau hasil reklamasi di wilayah perairan pantai, pasang surut, rawa, danau, dan bekas sungai dikuasai langsung oleh negara. Dalam pasal ini diberikan kepastian hukum terhadap keabsahan tanah hasil reklamasi, walaupun sampai pada ketentuan bahwa tanah itu di kuasai langsung oleh negara. 
Selain itu terdapat Surat Edaran Menteri Negara Agraria/Kepala BPN Nomor : 410-1293, tertanggal 9 Mei 1996, Perihal : Penertiban Status Tanah Timbul dan Tanah Reklamasi. Dalam SE BPN tersebut di tentukan dalam butir (3) bahwa : “Tanah-tanah timbul secara alami seperti delta, tanah pantai, tepi danau/situ, endapan tepi sungai, pulau timbul dan tanah timbul secara alami lainnya dinyatakan sebagai tanah yang langsung dikuasai oleh negara. Selanjutnya penguasaan/pemilikan serta penggunaannya diatur oleh Menteri Negara Agraria/Kepala Badan Pertanahan Nasional sesuai dengan peraturan perundangan yang berlaku”.

Perkembangannya untuk melaksanakan ketentuan reklamasi berdasarkan Pasal 34 ayat (3) UU 27/2007 telah di atur dalam sebuah Keputusan Presiden Nomor 122 Tahun 2012 tentang Reklamasi di Wilayah Pesisir dan Pulau Pulau Kecil (Lembaran Negara Republik Indonesia Tahun 2012 Nomor 267), dan di jabarkan lebih lanjut dalam Peraturan Menteri Kelautan dan Perikanan Nomor 17 Tahun 2013 Tentang Izin Reklamasi.

Peraturan Presiden ini sesuai dengan Pasal 34 butir (3) UU 27/2007 ditetapkan dan disahkan ditujukan untuk perencanaan dan pelaksanaan reklamasi.

Reklamasi yang dilakukan di wilayah pesisir merupakan salah satu kegiatan pemanfaatan ruang yang sebenarnya telah merubah fungsi kawasan tersebut, misal wilayah pesisir yang sebelumnya sebagai kawasan lindung atau sebagai kawasan konservasi oleh karena dilakukan reklamasi maka akan beralih fungsi. Pemanfaatan ruang wilayah yang tidak berdasar tentunya akan membawa dampak yang kompleks tidak hanya bagi tata kehidupan bermasyarakat dan bernegara tetapi juga mengancam kelangsungkan kehidupan manusia dengan alam.

Ruang perlu ditata agar dapat memelihara keseimbangan lingkungan dan memberikan dukungan yang nyaman terhadap manusia serta mahluk hidup lainnya dalam melakukan kegiatan dan memelihara kelangsungan hidupnya secara optimal. (Hesty Hastuti, 2011 : hal. 3) Karena ruang merupakan tempat interaksi sosial, maka dalam penataan ruang tentu akan bersinggungan dengan masyarakat sebagai elemen di dalam ruang itu sendiri. 
Ruang berdasarkan Pasal 1 Undang-undang Nomor 26 Tahun 2007 tentang Penataan Ruang, diundangkan dalam Lembaran Negara Republik Indonesia Tahun 2007 Nomor 68 Tambahan Lembaran Negara Republik Indonesia Nomor 4725 (selanjutnya di sebut sebagai UUPR nomor 26 tahun 2007 disebutkan bahwa: "Ruang adalah wadah yang meliputi ruang darat, ruang laut, dan ruang udara, termasuk ruang di dalam bumi sebagai satu kesatuan wilayah, tempat manusia dan makhluk hidup lain, melakukan kegiatan, dan memelihara kelangsungan hidupnya”.

Penataan ruang berdasarkan wilayah administratif dalam UUPR nomor 26 Tahun 2007 terbagi dalam wilayah nasional, provinsi dan kabupaten / kota. Untuk itu setiap kegitan pemanfaatan ruang tunduk pada pengaturan penataan ruang dimasing masing wilayah.

Pada kebanyakan perencanaan tata ruang, masyarakat acapkali dilihat sekedar sebagai konsumen yang pasif. Memang mereka diberi tempat untuk aktivitas kehidupan, kerja, rekreasi, belanja dan bermukim, akan tetapi kurang diberi peluang untuk ikut dalam proses penentuan kebijakan dan perencanaannya. Padahal, sebagai mahkluk yang berakal dan berbudaya, manusia membutuhkan rasa penguasaan dan pengawasan (a sense of mastery and control) terhadap habitat atau lingkungannya. Rasa tersebut merupakan faktor mendasar dalam menumbuhkan rasa memiliki untuk kemudian mempertahankan atau melestarikan. (Hesty Hastuti, 2011 : hal. 3)

Bila masyarakat tidak dilibatkan dalam proses perencanaan dan pembangunan lingkungannya, tidak diberi kesempatan untuk bertindak secara aktif memberikan “cap” pribadi atau kelompok pada lingkungannya, tidak memperoleh peluang untuk membantu, menambah, merubah menyempurnakan lingkungannya, akan kita dapatkan masyarakat yang apatis, acuh tak acuh, dan mungkin agresif. (Hesty Hastuti, 2011 : hal. 4)

Penataan ruang sebagai suatu sistem proses perencanaan tata ruang, pemanfaatan ruang dan pengendalian pemanfaatan ruang guna kesejahteraan masyarakat harus menyertakan partisipasi masyarakat dalam setiap tahapannya. Hal tersebut terlebih karena penataan ruang bukanlah semata-mata suatu kegiatan yang 
rasionalistik, teknis dan estetis tetapi merupakan pula proses sosial politis yang dinamis dan sarat dengan konflik. (John Forester, 2011 : hal. 5)

Oleh karena itulah, semua kegiatan penataan ruang di Indonesia secara yuridis memang semestinya berpaling pada UUPR sebagai “Legal Base”. Berdasarkan UUPR akan senantiasa dilakukan penataan ruang dengan segala aspek perencanaan tata ruang maupun prosedur perencanaan tata ruang. Hal ini berarti bahwa secara normatif, pelaksanaan tata ruang di indonesia merupakan perwujudan atau pencerminan dari substansi UUPR. Melalui penataan ruang yang bertumpu pada UUPR niscaya diadakan pendayagunaan dan pemanfaatan ruang sesuai dengan peruntukannya. (Pratetijo Riyadi, 2005 : hal. 5)

Namun bila kita melihat fakta masih banyak kegiatan-kegiatan pemanfaatan ruang terutama untuk reklamasi pantai di wilayah pesisir tidak mengindahkan aturan dalam implementasinya.

Reklamasi oleh masyarakat lokal di pesisir selatan Madura yang dilakukan dengan cara mengurug pantai berikutnya berdampak pada status hak lahan hasil reklamasi. Lahan tersebut akhirnya di kategorikan sebagai tanah yang mempunyai hak untuk didaftarkan.

Meskipun kewenangan daerah dalam hal ini hanya mengatur pelaksanaan reklamasi dan tidak pada kewenangan dalam menerbitkan hak atas tanah hasil reklamasi tersebut, berdampak pada tidak adanya koordinasi antara BPN dan unsur Pemerintah Daerah, sehingga sertifikat hak atas tanah hasil reklamasi tersebut berdiri bangunan yang seringkali memanfaatkan ruang yang peruntukannya tidak sesuai dengan RTRW. Pada proses pendaftaran tanah Kantor Pertanahan sebagai otoritas hak atas tanah tidak pernah melibatkan pemerintah daerah, sepanjang secara administrasi sudah lengkap maka kantor pertanahan akan menerbitkan sertifikat meskipun banyak di temukan manipulasi data secara yuridis.

Reklamasi yang di lakukan oleh masyarakat lokal di pesisir selatan Madura bisa jadi disebabkan tidak adanya akses dan partisipasi mereka dalam proses legislasi RTRW Kabupaten, sehingga mereka tidak menyadari bahwa kegiatan reklamasi tersebut telah melanggar pemanfaatan fungsi ruang kawasan. Tidak berhenti pada 
pelanggaran pemanfaatan ruang saja akibat kegiatan reklamasi di pesisir selatan Madura, tanah hasil reklamasi menyisakan permasalahan pada proses dan mekanisme penerbitan sertifikatnya, karena tidak adanya koordinasi antara Kantor Pertanahan dengan Lembaga Teknis Daerah yang berkaitan dengan pelaksanaan reklamasi.

Melihat fakta tidak terpenuhinya azas manfaat pada seluruh kebijakan yang di ambil oleh keempat Kabupaten di wilayah Madura dalam menangani pelaksanaan reklamasi, sudah seharusnya di berikan jalan keluar melalui pengaturan reklamasi berbentuk "Peraturan Daerah”.

Peraturan daerah ini bertujuan untuk mewujudkan keterpaduan dalam pengaturan reklamasi khususnya di daerah, terutama ketika mengimplementasikan kewenangan di daerah berdasarkan Undang-Undang 23 Tahun 2014 tentang Pemerintahan Daerah, yang tidak tegas mengatur kewenangan daerah dalam mengelola wilayah laut, di samping itu untuk mengatur juga banyaknya lembaga teknis yang terlibat agar semakin jelas dan tegas kewenangannya serta fungsi koordinasinya.

\section{Simpulan}

1. Karakteristik penguasaan hak atas tanah hasil reklamasi di wilayah pesisir selatan Madura diperoleh melalui : Ijin dari Kepala Desa, bersertifikat dari BPN, bahkan ada yang tidak berijin/illegal. Sedangkan pihak yang menguasai kebanyakan perseorangan tetapi ada juga perusahaan atau badan hukum lainnya, termasuk instansi pemerintah. Peruntukan sebagaian besar untuk rumah tinggal dan sebagian lainnya usaha baik tambak maupun non tambak.

2. Kebijakan yang dilakukan terhadap pelaksanaan reklamasi di wilayah Madura masih bersifat sektoral, sehingga tidak terwujud keterpaduan dalam mengaturnya. Masing-masing lembaga teknis pemerintah daerah terkait reklamasi antara lain Perijinan, Bappeda, Dispendaloka, Kelautan dan Perikanan, menjalankan fungsi kewenanganya sendiri-sendiri, bahkan BPN sebagai otoritas penerbit sertifikat tidak pernah berkoordinasi dengan pemkab setempat dengan alasan hanya berdasarkan persyaratan administratif dan 
menyatakan tidak ada Perda yang mengaturnya. Hal ini ironis dengan keempat wilayah Kabupaten tersebut yang sudah memiliki Perda RTRW. Tidak terciptanya keterpaduan dalam mengambil kebijakan pelaksanaan reklamasi antar lembaga teknis pemerintah maka diperlukan pengaturan hukum secara tersendiri tentang reklamasi. Oleh sebab itu payung hukum berupa "Peraturan Daerah” tentang Reklamasi diperlukan untuk mengatasi problem kewenangan antar lembaga teknis pemerintah baik pusat maupun daerah.

\section{E. Persantunan}

Ucapan terimakasih tak terhingga kepada Dit.Litabmas Dirjen Dikti, Kementerian Riset, Teknologi dan Perguruan Tinggi yang telah mendanai penelitian ini pada TA 2013-2014 melalui program penelitian hibah bersaing

\section{F. Daftar Pustaka}

Bambang Sunggono. 1998. Metodologi Penelitian Hukum. Jakarta : PT. Raja Grafindo Persada.

Forester, John. 1989. Planning in the Face of Power. California: University of California Press.

Flora Pricilla Kalalo. 2009. Kebijakan Reklamasi Pantai dan Laut : Implikasi Terhadap Hak Masyarakat Pesisir dan Upaya Perlindungannya. Jurnal Hukum dan Pembangunan. Tahun ke 39 Volume 1 Januari-Maret 2009

Hesty Hastuti. 2011. Laporan Penelitian Hukum tentang Peran Serta Masyarakat dalam Pengaturan Tata Ruang, BPHN. Kementerian Hukum dan HAM.

Peter Mahmud Marzuki. 2005. Penelitian Hukum. Jakarta : Prenada Media.

Pratetijo Riyadi. 2005. Pembangunan Hukum Penataan Ruang Dalam konteks Kota Berkelanjutan. Surabaya : Airlangga University Press.

Radar Madura (Jawa Pos Group), Edisi 17 Maret 2012

Sanapiah Faisal. 1990. Penelitian Kualitatif (Dasar-dasar Aplikatif). Malang Yayasan Asih Asah Asuh

http://green.kompasiana.com/penghijauan/2011/08/06/abrasi-pantai-dan-hutanmangrove-384428.htm, di unduh pada 24 Maret 2012

http://www.surabayapost.co.id/?mnu=berita\&act=view\&id=3171fe993de3e8e874999 7cffdb531ab\&jenis=1679091c5a880faf6fb5e6087eb1b2dc

Undang-Undang Nomor 23 Tahun 2014 tentang Pemerintahan Daerah

Undang-Undang Nomor 27 Tahun 2007 tentang Pengelolaan Wilayah Pesisir Dan

Pulau-Pulau Kecil Lembaran Negara Republik Indonesia Nomor 84, Tambahan Lembaran Negara Republik Indonesia Nomor 4739 disahkan di 
Jakarta tanggal 17 Juli 2007 berikut perubahannya dalam Undang-Undang Nomor 1 Tahun 2014

Undang-undang Nomor 26 Tahun 2007 tentang Penataan Ruang Nasional LNRI Tahun 2007, TLNRI Nomor 4725

PP Nomor 68 Tahun 2010 tentang Bentuk dan Tata Cara Masyarakat Dalam Penataan Ruang

Peraturan Daerah Kabupaten Bangkalan Nomor 10 Tahun 2009 tentang Rencana Tata

Ruang Wilayah Kabupaten Bangkalan (Lembaran Daerah Kabupaten Bangkalan Tahun 2009 Nomor 4/E)

Peraturan Daerah Kabupaten Sampang Nomor 7 Tahun 2012 tentang Rencana Tata Ruang Wilayah kabupaten Sampang Tahun 2012-2032 Lembaran Daerah Kabupaten Sampang Tahun 2012 Nomor : 7

Peraturan daerah Nomor 16 Tahun 2012 Kabupaten Pamekasan tentang Rencana Tata Ruang Wilayah Kabupaten Pamekasan Tahun 2012-2032 Lembaran Daerah Kabupaten Pamekasan Tahun 2012 Nomor 6 Seri E

Peraturan daerah Nomor 12 Tahun 2013 Kabupaten Sumenep tentang Rencana Tata Ruang Wilayah Kabupaten Sumenep Tahun 2013-2033

Surat Edaran MENTERI NEGARA AGRARIA/KEPALA BADAN PERTANAHAN

NASIONAL Nomor : 410-1293, tertanggal 9 Mei 1996, Perihal : Penertiban Status Tanah Timbul dan Tanah Reklamasi. 